\title{
The Permeation of Humanistic Mind in College Education and Teaching
}

\author{
Baohong Li \\ College of electrical information engineering \\ Dalian university of JIAOTONG \\ Dalian, China
}

\begin{abstract}
This paper analyzes the significance of permeating humanistic mind in the process of college teaching, and puts forward some methods to permeate humanistic mind in the process of teaching.
\end{abstract}

Keywords-Teaching process; Penetration; Humanistic mind; University student; Permeate

\section{INTRODUCTION}

Mind is a pluralistic, open and developing concept, which reflects people's cultural value and concept of social subject consciousness, which is through long-term cultural practice. Gradually accumulated and sublimated, but also with the development of society and development, and has a certain national cultural characteristics. The sense of mission, responsibility, humanity, conscience principle, personality consciousness, harmony between Man and Nature and humanism of Chinese fine cultural traditions are all the connotations of humanistic mind. The modern university is responsible for the training of advanced specialized talents for the social and economic development and the modernization construction. Of course, it must run through the education of mind. [1] It is not only the task of the humanities, but also the necessity to permeate and permeate the teaching process of all the majors and disciplines in the university.

\section{THE IMPORTANCE OF PERMEATING THE HUMANISTIC MIND}

In the course of college teaching, how to permeate the reality of mind has aroused people's attention to this problem. Education and the future of the nation, teachers are the engineers of the human soul, teachers are the responsibility of teaching, school education to pursue a quality of education, mutual care, warm atmosphere. Cherish the present moment of students, constantly enlighten and guide students, help them establish a sense of responsibility and sense of mission, let classroom teaching arouse the potential of students, when our education, our teachers, This ability of self-development cannot be underestimated after stimulating and awakening students' potential. [2] At present, due to the development of market economy, colleges and universities are faced with the choice of society. Many factors have combined into the absence of humanism in university education and teaching. College students are active in thought, quick in response to all kinds of thoughts and extreme in convergence psychology, so they are most vulnerable to the influence of all kinds of thoughts, especially the bad ideological virus in society. For example, money first, material enjoyment, mixed diploma, cognitive decadence, psychological extreme, and so on, a number of colleges and universities into the mainstream of the vitality of health and progress. Therefore, while cultivating and improving students' professional theories and skills, we should pay attention to the healthy development of their thoughts and promote the all-round development of their physical and mental qualities. It is not only beneficial to train students in the pattern of contemporary multiple thinking and ideas, to ensure the firmness and consistency of a rational belief, and to absorb the achievements of contemporary civilization, so that it is full of immortal vitality. At the same time, the teaching process is the main activity of the students, and it is the most important part of the students' time consuming. It is not just the political class and other ideological education activities. This also realized to the university student's entire journey education and the humanities concern.

\section{HOW TO PERMEATE HUM ANISTIC MIND IN TEACHING PROCESS}

\section{A. Adhere to the Idea of Putting People First}

The idea of humanism has called for the essential improvement of people's life and overall quality under the market economy, and the competition for survival in modern society is very fierce. People, especially young people, often face the conflict between mind's pursuit and survival. As a result, it may lead to two extreme characteristics of modern mind's situation. The mind is empty; Second, materialism, greed for material things. Against this background, the introduction and emphasis of humanism can give people an open vision and a broad mind so that they do not sink into the modern whirlpool of labor and consumption. So that the guidelines of spiritual life have a higher direction and positioning, college students should be grateful to their parents, grateful to teachers, grateful to society, a grateful heart, will be full of sunshine. A student does not know gratitude, always feel that his parents are sorry for him, his classmates are sorry for him, the teacher is also hard on him, his heart will become more and more gloomy, depressed, even depraved. Everyone needs to find the motivation to make progress, which may come from self-esteem, self-improvement, may come from gratitude, may come from the desire to change poverty, This is 
the driving force that radiates the fervor of struggle. Emphasizing the permeation of humanistic thought through the teaching process, emphasizing the function of deep mind's meaning, which is mainly about the ultimate concern of human being, first of all, Zhang's consciousness of human being in the course of teaching. The standpoint of teacher's ethics puts love in the first place, good guidance to the students. Cherish the precious time to study mainly, teachers through the care, education and training of students to achieve the goal of talent training in institutions of higher learning, followed by strict requirements for teachers in the teaching process. [3] The outpouring of students' negative and decadent thoughts and other problems, We should not simply deal with it, let alone let it go, think that it has nothing to do with ourselves, but should be based on the premise of love to guide and correct.

\section{B. Exploring and Developing the Humanistic Connotation of the Specialized Subject}

Although different disciplines differ in their expertise and in the way they perceive the world, none of these theoretical knowledge and skills are created out of thin air and are the result of long human practice and thinking. It must contain the gene of mind. Students are required to overcome certain cognitive biases, teachers as long as deep excavation, which can be found in the humanities of mind. For example, the course of Electrotechnics has enabled students to be educated in dialectical materialism and patriotism, and the development of electrical technology in the 19th century has led to the transformation of mankind from the era of mechanization to the era of electrification. The development of electronic technology after the 20th century has promoted the rapid development of communication, control and computer, the combination of computer communication technology and so on, is promoting the fundamental change of information technology, 5Gcommunication,Autonomous driving, the emergence of the Internet of things, so that people began to enter the global information age. Paying attention to the education of the students' contradictory movement, development and change in teaching can make the students form dialectical view and methodology in the course of learning. [4] At the same time, let students look at things in a more comprehensive way, and cultivate dialectical thinking and innovation awareness of the human quality. For example, the Chinese language curriculum is a collection of Chinese traditional human essence, leaving the human nature of the Chinese language, it is impossible to reveal its origin and development; Other disciplines, such as all hidden rich in human thought, teachers are good at digging, and conscious hair, can be a clever display of human thought, to the students and cultivate.

\section{Devote Oneself to the Construction of Humanistic Atmosphere in Teaching Process}

At present, the teaching of university specialized courses takes up most of the students' time, and has been paid much attention to by students. Teachers teach a course, in addition to the teaching of their professional knowledge, should have three kinds of influences on students. The first is the influence of teachers' own image on students. Teachers in the teaching process of beautiful teaching, incisive analysis, rigorous reasoning, neat book, vivid language and exquisite teaching AIDS, and so on, can give students the enjoyment of beauty. It is the important connotation of the harmonious humanistic atmosphere to put the beauty of science in the whole teaching process, and to build up the harmonious classroom atmosphere, so that students can acquire theoretical knowledge and skills at the same time. Get the feeling of inner emotion and beauty, realize the coordinated development of mental skills, which completes the organic integration of humanistic mind cultivation and professional teaching. [5] The second is to train the students' thinking methods through the study of the curriculum. The teaching process in colleges and universities is prominent because of its theory. With the help of multimedia facilities, teachers can create a vivid and colorful teaching atmosphere by simplifying and visualizing complex and abstract theories, adding to the metaphor of the process. Encouraging students to mobilize positive factors, And then train students to love professional theory, pay attention to the classroom, teaching design, as individual content to be distributed to the macro-side to consider. So that students can understand and think from a broader perspective of the connection between the new and the old theories and knowledge, so that the humanistic mind embodied in the teaching contents can expand to a wider and deeper extent, so as to provide more human information to the students. So that students from point to face in the rich contact and imagination of the thinking process, more strongly feel the shock of the humanities mind, has achieved better results. The third is that every subject has a close relationship with the development of society and human beings. Students can establish a strong sense of social responsibility by understanding this relationship. Education should be faced with the human soul, educators should be lit by the fire of the mind of the educated, given to the people should have the freedom, dream, dignity and the pursuit of happiness. [6] Interspersed with national history, fine culture, fine tradition, and the history and stories of scientific inventions, How are the mysteries of nature revealed to students and how to ask questions? How to solve problems, understand the nature of various disciplines, social functions, the impact of disciplines on human destiny, etc., to arouse students' attention to society, history, life and the future. Engage in scientific enthusiasm to help them cultivate their own humanities mind, become a high-quality talent.

\section{CONCLUDING REMARKS}

In the course of university teaching, the infiltration of people's thoughts is of great significance. Teachers, through the renewal of ideas and the reform of teaching methods, from the point of view of people's concern. Do everything possible to increase the humanistic sentiment of subject teaching, to permeate the humanistic thought into the whole process of teaching, to pay attention to mind's life and respect mind's value, which is the most profound connotation of humanistic mind. The development of economy brings the future of more expensive civilization and prosperity. The future of civilization and prosperity needs more humanistic care. Taking the development of all-round human freedom as the highest goal and striving to implement it, in such an era, education must first assume the important responsibility of humanistic care. And the cultivation of mind as the highest goal of education, 
and strive to implement. Only in this way can we promote the improvement of students' professional theoretical skills and the overall development of their physical and mental quality.

\section{REFERENCES}

[1] Qi Shen Construction of campus culture and reconstruction of university mind and university education theory[J]. Education century, 2004.10.( In Chinese).
[2] Yifan Mu The idea of good university and the construction of university culture[J]. Research in education, 2004.3.( In Chinese).

[3] Zhongfu Wu, Jialin Zhu On the integration of humanistic education and scientific education and its realization mechanism[J]. Research on higher education in China, 2012.12.( In Chinese).

[4] Jimei Ren Probe into the ways to improve college students' humanistic quality[N]. Joumal of Neimenggu normal university, 2010.11.( In Chinese).

[5] Liangping Shi The connotation and function of college students' humanistic quality[J]. Good parent, 2016.46.( In Chinese).

[6] Heng Yu An analysis of the way of humanistic quality education for college students[J]. Time education, 2018.13.( In Chinese). 